\title{
REFLEXÕES SOBRE A FORMAÇÃO INICIAL DE PROFESSORES: UMA ANÁLISE SOBRE O ESPAÇO DA SUPERVISÃO DE ESTÁGIO
}

\author{
CONSIDERATIONS ON TEACHER'S INITIAL \\ EDUCATION: AN ANALYSIS ON THE INTERNSHIP \\ SUPERVISION ENVIRONMENT

\begin{abstract}
REFLEXIONES SOBRE LA FORMACIÓN INICIAL DE PROFESORES: UM ANÁLISIS SOBRE EL ESPACIO DE LA SUPERVISIÓN DE ETAPA
\end{abstract}

Rita de CAssia CRistofoleti ${ }^{\mathrm{I}}$ ${ }^{\mathrm{I} U n i v e r s i d a d e ~ F e d e r a l ~ d o ~ E s p i ́ r i t o ~ S a n t o ~(U F E S), ~ S a ̃ o ~ M a t e u s / E S ~-~ B r a s i l ~}$

\begin{abstract}
RESUMo Este estudo discute sobre os encontros de supervisão de estágio como espaços formadores da profissionalidade docente. Ancorado nos estudos de M. Bakhtin acerca da linguagem e seu funcionamento nas relações sociais e de sua centralidade na constituição dos sujeitos, na produção e compreensão dos conhecimentos em circulação na vida social, compreende a formação de professores como um processo de produção de sentidos. Sem negar a linguagem como possibilitadora da comunicação, Bakhtin atribui a ela um papel mais amplo do que esse, ao defini-la como central no processo de humanização do homem. Segundo ele, a especificidade da constituição histórico-cultural dos seres humanos radica no fato de que seu acesso à realidade é sempre mediado pela linguagem. Partindo desse pressuposto, o texto apresenta uma análise a respeito de um dos encontros de supervisão de estágio, ocorrido num curso de Pedagogia de uma faculdade particular do interior do Estado de São Paulo.
\end{abstract}

Palavras-chave: Estágio Supervisionado; Formação Inicial de Professores; ProduÇÃO DE SENTIDOS.

AbSTRACT This article discusses the internship supervision meetings as a place of teacher's professional development. Based on M. Bakhtin's studies about language, its usage in social relations, and his centrality on the subject's constitution and in the production and comprehension of knowledge that circles social life, the teacher's education is a process 
of producing senses. Without denying language as a communication possibility, Bakhtin attributes to it a wider role in the humanization process of human being. For him, the specificity of historical-cultural perspective relies on the fact that the access to reality is always mediated through language. From that assumption, the article outlines an analysis of one of the internship meetings, from a Pedagogy course, in a private countryside university on São Paulo state, Brazil.

Keywords: Internship supervision; Teacher's initial education; Senses production.

RESUMEN Este estudio discute sobre los encuentros de supervisión de prácticas como espacios formadores de la profesionalidad docente. Anclado en los estudios de M. Bakhtin acerca del lenguaje y su funcionamiento en las relaciones sociales y de su centralidad en la constitución de los sujetos, en la producción y comprensión de los conocimientos en circulación en la vida social, comprende la formación de profesores como un proceso de producción de sentidos. Sin negar el lenguaje como posibilitadora de la comunicación, Bakhtin atribuye a ella un papel más amplio que ese, al definirla como central en el proceso de humanización del hombre. Según él, la especificidad de la constitución histórico-cultural de los seres humanos radica en el hecho de que su acceso a la realidad es siempre mediado por el lenguaje. A partir de ese presupuesto, el texto presenta un análisis sobre uno de los encuentros de supervisión de prácticas, ocurrido en un curso de Pedagogía de una facultad particular del interior del Estado de São Paulo.

Palabras clave: Etapa Supervisada; Formación Inicial de Profesores; Producción DE SEnTIDos.

\section{INTRODUÇÃo}

Este texto tem como objetivo analisar um dos encontros de supervisão de estágio ocorrido em uma faculdade particular do interior do Estado de São Paulo, na tentativa de compreender como as relações de supervisão de estágio, ao instaurarem um espaço de interlocução sobre a docência, a escola e a formação acadêmica inicial, afetavam os estagiários e seus formadores. Para tanto, assumi os encontros presenciais de supervisão dos quais participava na IES em que atuava ${ }^{1}$ como professora, como lócus da pesquisa e a dinâmica interlocutiva neles produzida como "objeto" de análise.

Elegi como participantes da pesquisa as alunas ${ }^{2}$ que frequentavam o $5^{\circ}$. e $6^{\circ}$. períodos do curso de Pedagogia, cujos estágios acompanhei, como supervisora, durante dois anos. Minha escolha por abordar a formação de professores como um processo de produção de sentidos aproximou-me das teses de M. Bakhtin acerca da linguagem e seu funcionamento

1 Uma instituição privada pertencente a uma congregação religiosa católica, localizada no município de Piracicaba, interior do Estado de São Paulo, Brasil, que atendia basicamente a uma demanda local por formação superior, oferecendo cursos nas áreas de Administração, Ciências Contábeis e Pedagogia, todos no período noturno.

2 Referi-me aos sujeitos da pesquisa no feminino porque a turma era composta por 17 mulheres. Com idades entre 18 e 40 anos, a maioria delas trabalhava oito horas diárias como auxiliares de Educação Infantil ou no comércio da cidade. Apenas duas alunas eram donas de casa. A maior parte delas cursou a escolaridade básica em escola pública e viu, no curso noturno de Pedagogia, a possibilidade de inserir-se na carreira do magistério. 
nas relações sociais e de sua centralidade na constituição dos sujeitos, na produção e compreensão dos conhecimentos em circulação na vida social.

Na perspectiva semiótica de Bakhtin (1999), compreender significa produzir réplicas que se materializam em palavras, em gestos, no silêncio, na recusa, na adesão, nos modos de agir que são assumidos nas relações vividas entre sujeitos. Nessas réplicas, indiciam-se os sentidos elaborados e em elaboração pelos sujeitos na concretude das interações vividas.

Essa opção teórico-metodológica possibilitou-me apreender as particularidades dos sentidos produzidos no processo de formação em sua historicidade. Ou seja, o vivido imediato, nas supervisões de estágio, foi analisado em suas especificidades e em sua relação com o cotidiano escolar, bem como, os estagiários, seus formadores na universidade e na escola básica - professores, diretores, coordenadores, alunos, pais, funcionários - foram entendidos, todos, como pessoas ${ }^{3}$ portadoras de conhecimentos, interesses e valores, que ocupam distintos lugares sociais ${ }^{4}$ no sistema educativo. Mas também foi compreendido em sua relação com a história do Estado, sociedade e do sistema educacional em que se inseria; em sua relação com a história cívica e política locais; em sua relação com as relações de poder marcadas pelo sistema hierárquico dentro do qual as atividades dos sujeitos se inscrevem e se desenvolvem, definindo modalidades de comando e a atribuição de responsabilidades, e ainda em sua relação com os mecanismos estabilizados, nas formas de práticas e significados, que põem em funcionamento a própria escola e o próprio processo de formação.

Daí a importância de apreender, nos encontros gravados, ${ }^{5}$ indicadores dos sentidos da escola, da docência e da formação acadêmica em circulação e em debate na supervisão de estágio, bem como, de identificar quais desses sentidos eram privilegiados e como afetavam as compreensões em elaboração pelas estagiárias e pela própria professora supervisora acerca de seu papel como professora.

Os encontros de supervisão configuravam-se como momentos destinados ao esclarecimento de dúvidas, orientações, auxílio na elaboração de planos, projetos e relatórios. Neles também eram discutidos textos, as práticas vistas nas escolas, os modos de inserção dos estagiários na escola e na sala de aula, suas dúvidas e receios e as possibilidades e caminhos que vislumbravam em relação ao trabalho observado na escola.

3 O termo pessoas foi utilizado na acepção de Vygotsky, que o emprega para se referir à personalidade, à singularidade que vai se constituindo nos indivíduos na trama das relações sociais por eles vividas. Segundo Vygotsky, a pessoa, a personalidade é a síntese das suas relações sociais. Na personalidade, individual e social não estão opostos. Eles constituem uma forma superior de sociabilidade (VIGOTSKI, L. Manuscrito de 1929. Educação e Sociedade, Ano XXI, nº. 71, 2000, p. 21-44).

4 Esse conceito se refere aos modos diversos como os papéis sociais são ocupados e exercidos pelos sujeitos, em função da forma como se inserem no conjunto das relações sociais da escola. Por exemplo, entre os professores que exercem a mesma atividade na escola, há diferenças entre os lugares ocupados pelo professor antigo de casa e pelo professor iniciante, pelo professor de $6^{\circ}$. ao $9^{\circ}$. ano e pelas professoras do $1^{\circ}$. ao $5^{\circ}$., pelo professor que mora no bairro onde fica a escola e por aquele que vive fora dali etc. Do mesmo modo, entre os alunos, há diferenças de lugares entre aqueles considerados terríveis e aqueles que são considerados disciplinados, entre os que gostam das atividades da sala de aula e os que gostam mais do recreio, entre os populares entre os amigos e os que são isolados etc.

5 Para a realização da pesquisa foram gravados, em áudio, os encontros semanais de supervisão realizados pela pesquisadora, na condição de professora supervisora de estágio do curso de Pedagogia noturno de uma instituição confessional da cidade de Piracicaba (São Paulo, Brasil), com uma turma de 17 alunas. Nesse sentido, os sujeitos participantes da pesquisa assinaram o Termo de Consentimento Livre e Esclarecido. 
Nesse contexto, chamo de supervisão de estágio em acontecimento aquela em que as orientações e prescrições relativas aos estágios são reconhecíveis, ainda que não coincidam perfeitamente com o que se realiza. A supervisão em acontecimento se reveste de particularidades que nascem das inter-relações entre os sujeitos concretos que vivenciam os estágios e os encontros de supervisão e remetem aos diversos papéis que exercem, a seus modos de apresentar-se, a suas aspirações, a seus objetivos, aos graus de submissão que indiciam ter em relação a exigências sociais etc.

\section{A SUPERVISÃo DE ESTÁGIO EM ACONTECIMENTO: UMA ATIVIDADE CENTRADA SOBRE O PRÓPRIO PROCESSO DE FORMAÇÃ̃O}

Fundamentando-se teoricamente na perspectiva enunciativo-discursiva de Bakhtin $(1999,2000)$ se assume que a experiência discursiva individual se forma e se desenvolve em interação constante e contínua com os enunciados alheios, cada enunciado produzido não se limita ao seu conteúdo. Os enunciados concretos significam na espessura e nas instabilidades das relações sociais. Eles são arena de encontro e de confronto entre opiniões de interlocutores imediatos, de pontos de vista, visões de mundo, teorias, em circulação na comunicação cultural. Nesse sentido, cada enunciado concreto é um elo na cadeia da comunicação discursiva de determinado campo e está voltado para seu objeto, para os sujeitos a quem se endereça e para os discursos sobre esse objeto, concordando com eles ou deles discordando. Por se constituir a partir de outros enunciados, respondendo ativamente a eles, cada enunciado concreto contém sempre mais de uma voz - a sua e aquela, ou aquelas, em relação às quais ele se constrói - mesmo que elas não se manifestem no fio do discurso produzido (FIORIN, 2006).

Focalizados sob esse ângulo, que é o da dialogia conforme os pressupostos bakhtinianos, os enunciados produzidos pelos estagiários na relação de supervisão são mais do que uma descrição de sua vivência na escola, ainda que comportem essa descrição. De fato, os estagiários em suas verbalizações no contexto da supervisão de estágio tematizam diferentes situações vividas na escola e na sala de aula, falam da escola, dos professores, dos alunos com quem conviveram durante o estágio, dos modos de realizar a docência por eles observados, mas o fazem a partir de outra atividade e em outro momento.

Ao verbalizarem sobre o estágio, os estudantes já estão inscritos em outra atividade. Enquanto estão face a face com o real, estão centrados na observação, nas ações que se desenrolam diante deles ou das quais participam, nas anotações que fazem in loco. Na verbalização acerca do estágio eles estão diante da apresentação e da representação para o outro de uma situação. Nessa condição não estão mais face a face com o real, nem estão vivendo as situações verbalizadas. Na verbalização, os estagiários evocam eventos passados e revivem o vivido no presente. Tanto aquilo que é evocado, quanto o que é revivido são escolhas pessoais, mas não só, pois elas não independem das relações presentes do estagiário com seus interlocutores, de suas expectativas e intenções em relação a eles e a si próprio. Nesse sentido, o vivido no passado que é revivido no presente pertence a dois contextos de vida distintos: o do estágio acontecendo e o da supervisão de estágio.

A dupla pertinência, nas palavras de Clot (2007) é uma dupla inserção e a verbalização do estagiário sobre o estágio na supervisão já é outra atividade: uma atividade em que 
pela palavra dirigida ao outro o estagiário organiza o vivido, faz dele seu próprio objeto, sai dos limites do contexto dos valores nos quais sua vivência se realizou.

Assumida a ideia da dupla inserção e da diferenciação entre a atividade de estágio e a atividade de verbalização na supervisão, cabe destacar que o que os estudantes enunciam na supervisão não é o que necessariamente aconteceu na escola, mas aquilo que apreenderam estando na escola na condição de estagiários sob determinada orientação. De igual modo, embora o estagiário, em suas verbalizações a respeito da escola, direcione sua atenção a diferentes situações e aspectos da totalidade da docência em acontecimento, avalie as práticas produzidas na escola, manifeste estranhamentos, constrangimentos, faça perguntas, não é pertinente considerar o que ele diz como um retrato de suas percepções e de sua capacidade de autorreflexão. Seus enunciados são como aponta Bakhtin com especial clareza:

[...] produto da interação de dois indivíduos socialmente organizados [...]. A palavra dirige-se a um interlocutor: ela é função da pessoa deste interlocutor: variará se se tratar de uma pessoa do mesmo grupo social ou não, se esta for inferior ou superior na hierarquia social, se estiver ligada ao interlocutor por laços sociais mais ou menos estreitos [...] (BAKHTIN, 1999, p. 112).

Seus enunciados inscrevem-se em um "horizonte social" definido e são réplicas ativas às formas de organização da escola e do próprio estágio, à legislação que os ordena, aos discursos que configuram os projetos pedagógicos a eles referidos, às concepções de docência, de ensino, de educação escolar em disputa na formação histórica em que seu aprendizado está inscrito, à imagem do professor supervisor a quem ele se dirige.

As referências e significados culturais que participam dos enunciados constituem vozes sociais que expressam interesses e compreensões diversas, em consenso e em conflito, que os constituem, e a seus interlocutores, como memória de sentidos (passada e futura), como história e cultura e às quais respondem.

A interação viva dessas vozes sociais e as condições em que ela é produzida participam dos enunciados dos estudantes e dos supervisores, nas relações face a face da supervisão, indiciando-se nos usos da língua, na tonalidade expressiva de que se revestem, como também nas contradições, nas aproximações e consensos, no distanciamento, nas recusas e discordâncias, nos silenciamentos presentes na sua composição.

Do ponto de vista da dialogia, todo enunciado exibe seu direito e seu avesso, ou seja, as contradições constitutivas das diferentes vozes sociais que nele se manifestam. E, nesse sentido, longe de remeter à ideia de promoção do consenso, o conceito de diálogo, em Bakhtin, supõe a tensão entre vozes sociais em disputa, que modulam os sentidos da linguagem, configurando a compreensão como uma réplica ativa às palavras dos outros, que se produz no encontro/confronto entre essas palavras alheias e aquelas de que os sujeitos já se apropriaram e que os constituem. Como diálogo, a compreensão supõe, então, não apenas o reconhecimento dos significados e sentidos em jogo, mas uma tomada de posição frente a eles - de adesão ou de recusa, de acordo ou desacordo, de divergência ou de convergência, de conciliação ou de luta.

Dessa perspectiva, a supervisão não é uma atividade centrada no cotidiano da escola, embora passe por ele, mas centrada sobre a própria formação. Nesse contexto, o exercício de análise da supervisão em acontecimento é o que se apresenta no tópico a seguir. 


\section{Alguns fragmentos Selecionados sobre a SUPERVisão de estágio em ACONTECIMENTO}

Nesse dia, iniciei o encontro de supervisão lembrando o grupo da documentação de estágio que deveria ser entregue a mim na semana seguinte. Dessa documentação constavam os cronogramas assinados pela professora e pela diretora da escola comprovando a presença das estudantes na unidade escolar ao longo do semestre, os cronogramas assinados por mim atestando o tempo de elaboração dos relatórios e os cronogramas de presença nas supervisões de estágio. A entrega dessa documentação demarcava o fechamento do estágio no semestre. A referência a esses documentos suscitou a interlocução reproduzida a seguir.

Eu: Vocês estão fazendo o estágio nas escolas, vocês levam a documentação que precisa e a diretora assina, né? É só isso. Tem mais alguma coisa que estão pedindo para vocês levarem nas escolas?

Taiane: ${ }^{6}$ Por que, Rita, você está perguntando isso?

Eu: Porque teve uma diretora de uma escola que não quis assinar a documentação para uma das alunas da turma de vocês.

Gil: A diretora da escola em que estagiei também estava resistente. Eu cheguei lá na escola, falei que queria fazer o estágio. A diretora falou para mim: Então, eu não quero que você fique falando pra muita gente que aqui pode fazer estágio porque eu já tenho duas estagiárias de Pedagogia, mais não sei quanto de Psicologia e é muita gente. Foi super seca.

Aí beleza, como para mim ela autorizou, peguei e fiz as 40 horas no Ensino Fundamental. E tinha dez horas para fazer de direção, com ela. A professora da classe comentou com a diretora que eu "tava" ajudando na sala de aula. Então a diretora mudou comigo. Começou a me tratar superbem, e tudo o que ela fazia, dizia: Você quer me ajudar?

Eu: Que tipo de atividade ela pediu para você fazer?

Gil: No primeiro dia eu recortei todos os bilhetes da festa junina e fiz os canhotinhos da venda de votos da miss sinhazinha. Imagina, eram três canhotinhos para cada aluno e são mais de 300 alunos. Cortei tudo e levei tudo pronto pra ela. Fiquei até com dor nas costas.

No outro dia que eu fiz o estágio, ela tinha que fazer cadastro de alunos e era tudo manual. Tinha que transcrever todos os dados dos alunos. Me orientou a digitar certinho os nomes dos alunos, observar onde tinha acento, se escrevia com z ou com s. Eu fiz oitenta cadastros para ela. Quando eu peguei o jeito de fazer, acabaram as minhas horas de estágio.

A diretora agradeceu minha ajuda, falou que se eu tiver mais 30 horas de direção pra fazer que posso procurar a escola que ela aceita.

(Risos das alunas...)

Eu: Mas é assim mesmo. Você vai estagiar, lembra do que discutíamos no primeiro semestre de estágio, o estagiário não tem um lugar específico na escola, porque ele chega e depois vai embora de uma hora para outra. Lembra que eu dizia para vocês no início, vão conquistando seus espaços, quaisquer que sejam eles, e analisando o que estão aprendendo. Muitas vezes uma atividade que parece não ensinar nada, oportuniza uma aproximação com o pessoal da escola.

6 Os nomes das alunas, participantes da pesquisa, são fictícios. 
Essa aproximação viabiliza conversar e fazer perguntas sobre temas que interessam a vocês e para sua formação.

Gil: A diretora me disse que no semestre que vem as portas estarão abertas para mim e que se eu quiser continuar serei muito bem-vinda.

(10) Eu: Ainda bem, aí você volta lá. E é assim mesmo, se a gente chega com o nariz erguido, querendo dizer eu sei mais do que você, porque eu estou na faculdade, represento a academia, represento o saber, você perde mesmo. Agora se você chega e vai conquistando espaço, a escola tem as portas abertas.

Gente, pra essa aluna que a diretora não quis assinar, a escola era nova, a diretora estava lá há pouco tempo, não tinha ainda experiência com estagiária, ela queria uma autorização da Secretaria Municipal da Educação para que a estagiária pudesse entrar.

Gil: O meu só está faltando conferir se tem assinatura da professora e da diretora em todos os cronogramas para entregar na semana que vem.

Eu: Isso, confiram tudo, porque se faltar assinatura não posso validar como estágio feito.

Jade: (com uma expressão de desconforto e uma voz de enfado) Você acredita, Rita, que eu tenho que preencher os cronogramas tudo de novo e levar na escola para a diretora assinar?

Eu: Por quê?

Jade: ${ }^{7}$ Porque eu fiz errado, preenchi o número de horas errado e não pode ter rasura.

Eu: É, você saiu da escola meio brigada com a diretora, é isso? Por isso você não quer voltar?

Jade: Não, eu não saí brigada, mas também não saí naquela maravilha. Ainda bem que eu fiquei quieta.

Alana: ${ }^{8}$ A nossa diretora, a nossa chefa, ligou na escola que a Janaína ${ }^{9}$ estava fazendo o estágio chamando ela, porque estava precisando dela lá na escola. Mas a diretora da escola que ela estava estagiando falou: - Mas ela precisa fazer o estágio, agora que ela está aqui ela precisa terminar. Só vou assinar quando ela acabar. A diretora da escola que a Janaína estava estagiando estava defendendo a estagiária, estava defendendo a Janaína. Ela achava que a diretora da nossa creche não liberava a gente para fazer o estágio, por isso que ela respondeu assim.

A nossa diretora sabe que a gente tem que estagiar, mas... Não sei que cisma que os diretores, os professores têm da gente ficar fazendo o estágio. A filha dela estudou aqui, ela sabe que a gente tem que estagiar.

Eu: A cisma é a desconfiança. É que na supervisão a gente discuta...

Alana: Fale mal da escola e da professora.

Eu: E na verdade, nós estamos tentando entender a prática da professora. Embora a gente discuta, problematize, é sempre na tentativa de entender a prática e para vocês também se colocarem no lugar do outro. E se fossem vocês? Como é que lidamos com uma porção de coisas que acontece na escola, que a gente vê

7 Jade realizava o estágio na mesma escola em que trabalhava como professora em horário oposto ao do seu trabalho, mas havia discutido com a diretora e pedido demissão em função de discordar das exigências impostas ao seu trabalho, como, não fazer hora de almoço e precisar emendar o estágio curricular com o horário de seu trabalho como funcionária da escola.

8 Alana e Janaína trabalhavam na mesma escola de educação infantil municipal (creche) e realizavam o estágio supervisionado curricular em outra creche do município de Piracicaba.

9 Professora que trabalhava na mesma creche que Alana, mas que estava fazendo o estágio em outra creche. 
que a professora não está dando conta? Mas e se fosse a gente no lugar da professora? O que você iria fazer? Será que a gente estaria dando conta também?

Talita: Aconteceu isso comigo. Quando eu fiz o estágio na minha cidade, eu ainda não atuava na área. Aí eu falava: Nossa, dá para a professora fazer isso, fazer aquilo. Ela não faz, porque tem preguiça.

Agora que eu sei como é que é. Nesses últimos estágios que eu fiz, eu já fui com um outro olhar. Você não sabe o dia-a-dia da sala, você está ali dois dias da semana, você não sabe o que aconteceu nos outros dias.

Você vai aquele dia para a escola, acontece um fato isolado, que você não sabe por que foi que aconteceu, porque você não estava durante a semana. Então hoje, eu já procuro ver diferente.

Eu: Por isso que eu sempre oriento vocês a não ficarem um dia em uma sala e outro dia em outra sala. Acompanhem pelo menos uma semana uma mesma sala para vocês saberem. Porque, às vezes, vocês pegam no primeiro dia do estágio, os resquícios de uma briga, você não entende por que a professora e os alunos estão naquela agitação, porque você não acompanhou o dia anterior. $\mathrm{Ou}$, você termina o dia acompanhando uma problemática que você não sabe como no outro dia se resolveu, porque você não está lá naquela sala, com aquela professora e com aqueles alunos.

Talita: Aí a gente coloca no relatório, algo que não é verdadeiro.

Meus comentários sobre a necessidade das assinaturas das diretoras e das professoras das escolas para a efetiva validação do estágio e acerca da recusa de uma diretora em fazê-lo explicitaram as relações de poder constitutivas do estágio, que se assentam na hierarquia entre as instituições de ensino superior e a escola básica, entre diretores das unidades escolares e estagiárias, entre estagiárias e professora supervisora, entre professoras e diretoras das unidades escolares e a professora supervisora. Embora essa seja a temática abordada ao longo da interlocução, as relações de poder são mais sugeridas, mencionadas, supostas, do que abertamente analisadas pelos interlocutores.

Nos momentos propostos para análise, diferentes sentidos do estágio e do lugar da estagiária são destacados pelas estudantes e por mim. Neles também se indiciam imagens que os professores e gestores das escolas constroem dos estagiários e imagens que os estagiários e a professora supervisora constroem de si e dos profissionais da escola básica nas relações produzidas nos estágios.

\section{Estágio: QUAL É MESMo o SENTIDo DeSSa ATIVIDAdE? Estagiária: QUE LUGAR É ESSE?}

Foi em resposta ao meu comentário de que uma diretora não quisera assinar a documentação para uma das alunas da turma, que Gil, no primeiro momento recortado para análise, relata sua trajetória na escola (turnos 4, 6 e 9), passando do não acolhimento inicial ("A diretora da escola [...] estava resistente"; "Foi super seca") a sua aceitação como estagiária.

Nesse relato, Gil justifica sua aceitação pela diretora como uma consequência de sua disposição em colaborar, mais do que em observar a escola ("A professora da classe comentou com a diretora que eu 'tava' ajudando na sala de aula" - turno 4). 
A relação estabelecida entre ajudar, ser aceita como estagiária e cumprir o estágio é reafirmada por Gil quando ela descreve a mudança de atitude da diretora em relação a ela (“Começou a me tratar superbem"; “[...] tudo o que ela fazia, dizia: Você quer me ajudar?”) e quando destaca a disposição manifestada pela diretora, de voltar a recebê-la como estagiária para a finalização do estágio em outro momento (turnos 6 e 9).

Na sequência, ao ser questionada por mim acerca dos tipos de atividade que foi solicitada a realizar na escola (turno 5), Gil os descreveu e os avaliou em termos do volume de trabalho ("eram três canhotinhos para cada aluno e são mais de 300 alunos"; "oitenta cadastros") e de seus efeitos físicos sobre ela: cansaço e dor nas costas (turno 6).

Com esse modo de enunciar, Gil enfatizou características do estágio, que do ponto de vista da formação são consideradas como contingentes. A ausência, em seu enunciado, de referências ao valor das atividades por ela realizadas para sua formação como professora, relativizou o caráter formativo do estágio, sugerindo que, apesar de ser obrigatório, ele nem sempre resulta em aprendizados sobre a escola e a respeito da docência. Além disso, a ênfase, dada por Gil, ao resultado alcançado - garantir a continuidade do estágio e sua validação (turnos 6, 9 e 11) - conferiu à realização de atividades, na escola, o caráter de estratégia para assegurar o cumprimento do estágio e ao próprio estágio o sentido de tarefa a ser cumprida, mais do que uma relação de aprendizado.

O riso das demais alunas foi uma réplica ao relato de Gil e a mim. Embora não se possa assegurar de que sentidos se revestiu esse riso, é possível explorar algumas de suas possibilidades tendo em conta o papel atribuído por Bakhtin ao riso em seus estudos sobre a cultura popular no contexto da obra de François Rabelais.

De acordo com ele, o riso opõe-se ao esforço centrípeto dos discursos de autoridade, mostrando que os sentidos por eles pretendidos não são únicos, mas um entre outros. $\mathrm{O}$ riso das alunas, considerado dessa perspectiva, pode ser entendido como uma réplica à própria proposta de estágio, à supervisão e a mim, na condição de autoridade docente que as enuncia. Ele também indiciaria que a relativização do caráter formativo do estágio foi apreendida e que o fato de o contingente se tornar seu foco não é necessariamente algo tão ocasional quanto possa parecer aos supervisores de estágio.

Outra possibilidade de sentido indiciada pelo riso seria a familiaridade das estudantes com o sentido do estágio como tarefa e, até mesmo, sua concordância com a estratégia assumida por Gil para assegurar seu cumprimento e validação.

A ambivalência em relação aos sentidos do estágio - estágio tarefa/estágio formação - instaurada por Gil e mantida pelo riso das demais alunas foi replicada por mim nos turnos 8 e 10.

Começando meu enunciado com a expressão: "mas é assim mesmo" (turno 8), naturalizei, inicialmente, o fato de Gil assumir tarefas na escola e o tipo de relação estabelecida entre ela, a professora e a diretora em torno das mesmas.

Na sequência, reconstruí o significado do enunciado de modo a recuperar uma imagem defendida por mim em relação ao lugar do estagiário na escola. Lembrando que "o estagiário não tem um lugar específico na escola" (turno 8), indiquei a necessidade de "conquistar espaços" dentro dela, "quaisquer que sejam eles", como uma estratégia de inserção do estagiário nas relações ali produzidas. Com esses argumentos desloquei a naturalização 
dos vínculos entre estagiária e professores, inicialmente assumida, em favor de uma ação intencional dos estagiários para a construção dessa relação.

Porque não é uma relação espontânea, nem casual entre seres humanos colocados face a face, mas o encontro e confronto, anunciado e cercado de expectativas, entre sujeitos que ocupam lugares sociais distintos - o lugar de professor/a, diretor/a e o lugar de estagiário/a -, o estágio começa muito antes da chegada dos estagiários às escolas, como antecipação, como expectativas (tanto positivas, quanto negativas) de todos os sujeitos nele envolvidos.

Do ponto de vista das relações de poder, o estágio é marcado por ambiguidades e tensões. Em função de o papel social desempenhado pelo estagiário não existir fora da relação com o professor e com o diretor da escola em que ele se insere, mesmo quando essa relação é falseada e limitada à assinatura da ficha de estágio, conforme relatos que são feitos pelas alunas, sua posição parece a de submissão a eles. No entanto, ainda que o poder de aceitar ou de recusar, de validar ou não o estágio, confira, por um lado, poder e autoridade ao diretor e ao professor na relação de estágio, por outro, expõe esses dois profissionais e seus modos de ação ao olhar, à escuta e ao julgamento do estagiário. Nesse sentido, pode-se afirmar que os estagiários, professores e diretores afetam-se reciprocamente, tenham ou não consciência dessa reciprocidade.

Ao utilizar, em meu enunciado, a palavra "conquista" (turno 8) defini, sem explicitar, outra leitura da relação de poder presente no estágio que reafirma a assimetria, em detrimento da reciprocidade, só que em favor do estagiário. Como lembra Paulo Freire (1975) em seu ensaio "Extensão ou Comunicação?", a palavra conquista remete aos sentidos de invadir; apoderar-se; apossar-se; apropriar-se de algo, de uma relação, de uma situação ou de um espaço que pertence a outrem. Ao definir a necessidade de conquista de um lugar na escola, percebo que no momento desta análise, eu sugeri aos estagiários uma forma de ação, assentada na assimetria, que fortaleceria sua posição na relação de estágio, na medida em que ao apropriar-se de um espaço que é do professor e de relações conduzidas por ele, o estagiário o reduziria "a um mero objetivo de sua ação" (FREIRE, 1975, p. 41), uma vez que pensaria sobre o professor e acerca do lugar que ele ocupa, "mas não pensaria com ele" (IDEM), nem se submeteria a ele.

Em seguida à ideia de conquista de espaços, estabeleci uma segunda exigência à construção do estágio: a necessidade de os estagiários analisarem o que estão aprendendo. Com essa exigência, além de reafirmar uma posição de pensar sobre o professor e não com ele, introduzi um critério para a validação formativa daquilo que se viveu no estágio: as atividades assumidas na escola, quaisquer que sejam elas, contribuem para a formação desde que o estagiário analise aquilo que aprendeu acerca da escola e da docência, mediado por tais atividades.

Com essa modalização, não só reafirmei o fortalecimento da posição do estagiário na condução das relações de estágio, como também respondi ao tom irônico empregado por Gil, para avaliar as atividades por ela assumidas, e ao riso das alunas, deixando pistas de que a atuação na escola não deveria ser entendida apenas como ocupar-se de atividades prescritas por professores e diretores, nem apenas como uma forma de garantir a realização do estágio. Ela deveria ser entendida como um momento de aprendizado. Aprendizado esse dependente da aceitação de tarefas, tal qual descrito por Gil, mas também de uma atitude 
indagadora e analítica a ser necessariamente assumida pelo estagiário, o que o responsabilizaria por assegurar a dimensão formativa em sua experiência de estágio.

No turno 10, retomei a questão da aceitação da estagiária, contrapondo-me à tese defendida por Gil. Na réplica a ela, destaquei que as instituições (universidade, escola básica) e papéis sociais (estagiário, professor, gestor, formador universitário) envolvidos nas relações de estágio, não são apenas distintos entre si, mas hierarquizados e valorizados a partir dos lugares que ocupam na divisão social do trabalho (trabalho intelectual/trabalho prático) em nossa formação social. Com esse destaque, sinalizei as relações de poder como constitutivas das condições de realização do estágio, deslocando a suficiência da disposição em atuar na escola como a única forma de assegurar a aceitação do estagiário.

A partir dessa argumentação, retomei a proposta de conquista de espaço na escola, orientando as estagiárias para que não se apresentassem como representantes da universidade. Dei essa orientação sem analisar a relação de poder a que me referia, sem problematizar a própria ideia de conquista, sem considerar a condição de produção do estágio como parte de uma proposta de formação e sem analisar o jogo de imagens recíprocas que se estabelece entre seus participantes.

Como ressalta Fontana (2013), em ensaio sobre o processo de inserção do estagiário na escola, no encontro entre estagiários e os profissionais da escola básica se indiciam diferentes modos de compreender e valorar o vivido na escola e os saberes sobre ele produzidos, bem como, as políticas de conhecimento que regem e hierarquizam esses saberes.

\footnotetext{
De acordo com as concepções e valorações em jogo no processo de formação como um todo, o estudante pode apresentar-se nas relações de estágio como porta-voz das mudanças pedagógicas ou aprendiz que nada sabe; pode experimentar-se como um analista da escola ou como um participante em suas relações, como futuro professor, como pesquisador ou como professor-pesquisador, valorizando ou não o trabalho dos professores em atuação na escola básica e seus conhecimentos, reconhecendo-se, ou não, como parte integrante dessa escola em suas descontinuidades e contradições.

As imagens que o estagiário tem de si e de seus interlocutores são mediadas pelos livros que se lêem sobre a escola e seus rituais, pelos relatos de experiência que chegam aos estagiários por diversas vias, pelas orientações que os estagiários recebem de seus formadores, pelas negociações que se vão produzindo entre o estagiário e seus interlocutores (FONTANA, 2013, p. 143 e 144).
}

Sem fazer a análise do jogo de imagens que se estabelece nas relações de estágio, minha sugestão de não se apresentar como um representante da instituição formadora pareceu apagar o fato de que tanto o estagiário quanto os profissionais da escola básica sabem, de antemão, que ele tem um vínculo com essa instituição, que ele vivencia as relações na escola, orientado por uma proposta de formação e que sua aproximação da escola obedece a diretrizes por ela definidas. Com esse apagamento, tal orientação não só soa simplista por não explicitar e não analisar as relações de poder invocadas como argumento, como também parece sugerir a possibilidade de enganar as pessoas da escola para assegurar o estágio, conduta essa que estaria mais próxima do estágio como tarefa, a que eu mesma estava me contrapondo, do que do estágio como formação, por mim defendida. 
Nos turnos 8 e 10, embora eu não explicite os determinantes sociais da intencionalidade das relações produzidas no estágio, é a essa sua dimensão intencional que confiro ênfase, utilizando-me das expressões "vão conquistando", "vão analisando". O uso do gerúndio, indicando uma ação em andamento, insere esses dizeres no eixo da conduta, expressando aquilo que as estagiárias devem fazer. Com esses direcionamentos, responsabilizo as estagiárias por sua aceitação ou não na escola e pela manutenção do caráter formativo do estágio.

\section{O LUGAR DA ESTAGIÁRIA - CADÊ AS CONTRADIÇÕES?}

A responsabilização das estagiárias pelos rumos de seu estágio é replicada por Jade no turno 13. Nesse turno, inicia-se o segundo bloco de enunciados que recortei para análise. Nesse bloco, as considerações mais genéricas sobre o lugar do estagiário e acerca das condutas a serem assumidas pelas estudantes nas escolas são replicadas pela narração de casos específicos que colocam em evidência os limites da argumentação que se vinha tecendo em torno de duas interpretações contrapostas: o estágio como tarefa a ter seu cumprimento assegurado e o estágio como formação.

Embora distintas as duas interpretações, tinham como ponto em comum a ação intencionada dos estagiários na condução do estágio. Na primeira interpretação, a imagem do estagiário é a de alguém que, para assegurar sua aceitação e permanência na escola, assume intencionalmente tarefas prescritas pela professora ou pela diretora. Seu objetivo é cumprir o estágio tarefa.

Na segunda interpretação, o estagiário também é definido como alguém que age intencionalmente. Ele assume a condução do estágio pela conquista de espaços e não pela submissão àquilo que lhe é prescrito e pela análise do aprendizado implicado naquilo que vivenciou na escola. Suas ações são direcionadas ao aprendizado da docência.

Os relatos de casos específicos, por darem visibilidade aos limites dentro dos quais as relações de estágio são tecidas entre os sujeitos concretos, em condições históricas específicas, evidenciaram contradições na dicotomia estágio tarefa/estágio formação e na responsabilização do estagiário pelos rumos do estágio.

Demonstrando no tom de voz e na expressão facial, o desconforto que experimentava por ter que voltar à escola em que trabalhara para que a diretora assinasse novamente suas horas de estágio, Jade nos remete, a mim e ao grupo, à experiência conflitiva por ela vivida.

Em princípio, parecera interessante para essa aluna realizar o estágio na mesma escola em que trabalhava porque isso facilitaria seu processo de inserção. Mesmo tendo procurado diferenciar o estágio do trabalho que realizava na escola, cumprindo-o em horário oposto, a ocupação de dois papéis sociais distintos na instituição acarretou conflitos tanto nas relações de trabalho vividas quanto nas relações de estágio, na medida em que o lugar de trabalho acabou se sobrepondo ao de estagiária. Embora não apareça na interlocução transcrita, era recorrente a aluna reclamar de que no espaço em que ela estava atuando como estagiária, a diretora a via como funcionária da escola e pedia que ela realizasse as tarefas específicas de seu cargo como professora. Os conflitos intensificaram-se e a estudante acabou pedindo demissão da escola. 
Nos turnos 15 e 16, instaura-se entre nós uma disputa em torno de como definir o "lugar do estagiário na escola". Ao sinalizar, no turno 16, que reconhecia a situação a que ela se referia, utilizei-me da expressão "sair da escola meio brigada" para defini-la. Com tal expressão, responsabilizei Jade pelo conflito vivido, apagando as tentativas de negociação que ela relatara ao longo das supervisões.

Jade se contrapôs a meu enunciado, corrigindo-o: "Não, eu não saí brigada" (turno 17). Ela também questionou, ainda que não abertamente num jogo de réplica velada, tanto a ideia de colaboração do estagiário com a escola, defendida por Gil, quanto a necessidade de conquista de espaços e de análise do vivido defendida por mim, ao afirmar: "Ainda bem que eu fiquei quieta", lançando na interlocução outro modo de o estagiário estar na escola - o silenciamento.

Embora na tradição da racionalidade, conforme destaca Orlandi (1995), o silêncio seja interpretado como falta de sentido, quando considerado no jogo das relações sociais, ele é réplica: significa e é significado.

No caso de Jade, o silenciamento é uma réplica à diretora e a mim, na condição de supervisora de seu estágio. Na relação com a diretora, no jogo entre a organização do trabalho, como veículo da vontade de outro, e sua própria intencionalidade na condução do estágio, Jade atualizou no pedido de demissão, seu conflito com o poder, mas também preservou, pelo silêncio, a possibilidade de voltar à escola para conseguir a assinatura, requisito do qual eu não abriria mão para a validação de seu estágio. Com esses modos de agir, ela conciliou sua não submissão à diretora com a submissão às regras de validação do estágio.

Em relação aos meus dizeres sobre a intencionalidade das ações do estagiário e sobre a orientação a ser dada a elas no sentido da formação mais do que da tarefa, a situação concreta vivida por Jade evidenciou que sua opção pelo estágio formação colocou em risco o cumprimento do estágio tarefa, tão exigido por mim quanto o primeiro e mais decisivo para sua diplomação do que aquele.

Em resposta ao comentário de Jade e à minha observação sobre sua saída da escola, Alana fez um relato que confirmava que a distinção entre os papéis de funcionária e de estagiária não era algo simples entre os diretores das escolas, reafirmando as dificuldades vividas por Jade. Referindo-se a essa confusão de papéis como "cisma" desses profissionais em relação aos estágios das futuras professoras nas escolas, ela endossou a contraposição, enunciada por Jade, à ideia de estágio como uma relação de negociação que depende dos modos de agir da estagiária.

Embora, no enunciado de Alana, a palavra cisma remetesse aos sentidos de "implicância" e de "desconfiança" em relação às estagiárias (conf. turno 18), eu a interpretei como desconfiança em relação à instituição formadora na figura da supervisão (turno 19). Alana acolheu o sentido de desconfiança enunciado por mim e respondeu a ele completando meu enunciado ao associar a ideia de discussão a falar mal da escola e da professora (turno 20). Com essa escolha lexical, ela privilegiou um sentido de discussão: o de conflito, desavença.

Minha réplica ao enunciado de Alana, no turno 21, iniciou com a expressão "e na verdade", indicando que o que eu queria dizer com "discussão" não correspondia àquilo que Alana dissera, fazendo um reparo ao modo como ela complementara o meu enunciado. "E na verdade, nós estamos tentando entender a prática da professora." Com essa modali- 
zação, privilegiei outro sentido da palavra discussão, o de ponderação e, em torno dele, retomei objetivos do estágio: problematizar (no sentido de considerar), entender (no sentido de compreender, perceber, interpretar) as práticas apreendidas na escola. Nessa retomada, desloquei o sentido de antagonismo, a que eu mesma havia associado o estágio em resposta a Alana, em favor da ideia de aproximação, de reconhecimento do outro, do colocar-se no lugar do outro. Com esse posicionamento, me contrapus à ideia de conquista, entendida como ação sobre outro, que vinha norteando minhas argumentações em relação ao lugar do estagiário na escola. Embora eu mesma tenha percebido essa contradição só no momento da análise, ela é um relevante indicador de que as condições concretas de produção do estágio não afetam apenas as estagiárias, mas a própria proposta de estágio e a argumentação tecida, a seu respeito, no âmbito da supervisão.

No mesmo turno 21, na sequência de minha argumentação, dirigi uma série de perguntas às estagiárias (turno 21). Nessas perguntas, avaliei as professoras, ao assumir que há uma porção de coisas que acontecem na escola das quais elas não dão conta, mas também projetei uma avaliação das estagiárias, ao indagar se elas dariam conta também. Aproximei-as da situação escolar e das professoras e as induzi a analisarem a situação e a projetarem um modo de ação que, preferivelmente rompesse (que promovesse um cisma) com o desempenho observado.

Meu duplo julgamento - da professora e das estagiárias - explicita o desconforto intelectual (SCHWARTZ, 2000, 2001) que preside as relações de estágio. Do ponto de vista do estagiário, o desconforto é vivido, a partir dos desencontros entre o que o processo de formação valoriza, o que ele observa na escola e o que ele tenta fazer na escola, sem sucesso, a partir das orientações e princípios defendidos no processo de formação.

Do ponto de vista dos profissionais da escola básica, o desconforto nasce da exposição de si e de seus modos de ação ao julgamento do estagiário e de seu supervisor.

Do ponto de vista do supervisor, o desconforto se explicita na ambiguidade constante entre acolher o desconforto do estagiário, reconhecendo o desempenho criticável dos professores e da escola, e o cuidado em não negar o valor formativo de sua participação nas relações produzidas na escola. O desconforto também se manifesta no reconhecimento de que o estagiário necessita integrar-se à escola, assumir, mas que não deve se submeter totalmente, de que a dimensão formativa do estágio passa pela admissão da necessidade de superar muitas ações observadas na escola, mas sem negá-las pura e simplesmente, o que implica explicitar os limites das ações observadas e, a partir deles, projetar outros modos de agir.

O desconforto que preside as relações de supervisão materializa-se nas perguntas dirigidas às estagiárias, e não respondidas, e no conjunto de palavras em jogo na interlocução, que se referem a ações e sentimentos tanto das professoras e pessoas da escola como das estagiárias e da supervisora:

- Cismar (como cogitar, meditar) X cismar (como desconfiar, recear, duvidar, suspeitar).

- Cisma (como prevenção) X cisma (como ruptura, cisão).

- Discussão (como altercação, contenda, briga, conflito, desavença) X discussão (como disputa, controvérsia, polêmica, debate, contestação, ponderação).

- Falar mal (como opor-se, apontar o erro) X problematizar (como discutir, debater, considerar). 
- Entender (como compreender, perceber, interpretar, colocar-se no lugar do outro) X conquistar (como ocupar o lugar do outro, pensar sobre ele).

Tais palavras referem-se tanto às professoras, quanto às estagiárias, às diretoras e à supervisora de estágio, pois todas cismam e desconfiam, disputam, brigam e ponderam, falam mal e se entendem, julgam o outro e se colocam no lugar desse outro. Isso acontece porque as relações que se produzem entre os personagens do estágio são pautadas pela ocupação de lugares sociais hierarquicamente distintos, pelas diferenças geracionais, pelas políticas de conhecimento nela implicadas, que produzem sentidos divergentes acerca da docência, da escola, de seu cotidiano, das atividades que ali se desenvolvem e do processo de formação de professores.

Essas divergências, que são constitutivas da relação de estágio, levam os sujeitos, que dele participam, à demonstrações de autoridade e ao uso do poder de que os lugares sociais estão investidos, resultando em demissões, submissão às tarefas, silenciamentos ("Ainda bem que eu fiquei quieta"), estranhamentos e críticas, continuidade do estágio, não validação do estágio.

As contradições produzidas nas relações de estágio explicitam-se na supervisão e são incontornáveis. Uma dessas contradições é explicitada por Talita. Respondendo a mim, a Gil, a Jade e a Alana, ela inicia sua participação na conversa dizendo: "Aconteceu isso comigo" (turno 22). O isso a que Talita se refere é o julgamento que os estagiários fazem das professoras e também o exercício de se aproximarem da experiência delas.

Frente à complexidade da produção do lugar da estagiária na escola, do mesmo modo que não há um lugar definido de antemão, também não há estratégias de condução do estágio asseguradas por si mesmas. As condições de produção das relações entre os sujeitos envolvidos no estágio, pessoal e mediadamente, modulam a condução do estágio. A análise dessa diversidade de percursos é o que a supervisão de estágio proporciona em termos de aprendizagem tanto para as estagiárias quanto para a professora supervisora. Nessa análise, a escola é colocada no centro. Ela é, embora isso seja com frequência negado pelas propostas de formação, o modelo da ação profissional por exigir dos estagiários uma resposta a cada uma das situações que lá acontecem.

Madalena Freire (1986) sinaliza, acertadamente, que todo educador tem seus modelos e necessita deles e quem está se formando necessita, mais ainda, partir de um modelo, de um parâmetro, para poder superá-lo. O empréstimo do modelo referencial é uma condição da superação, pois como a criança, o aprendiz necessita introjetar modelos para daí "nascer" para o mundo maior. No estágio, em contato direto com o cotidiano da sala de aula e da escola como um todo, com os professores, diretores, coordenadores e suas práticas, o pedagogo em formação se vê diante de referências, de parâmetros de ação que incorpora pela concordância e pela refutação.

A supervisão, como ponto de confluência das diversas leituras que se tem da escola (inclusive as do supervisor), dos sujeitos, rotinas e atividades que a constituem, mediatiza a elaboração dos modelos referenciais emprestados, de seus pressupostos e dos valores neles implicados. Essa mediação não é neutra e, como os estagiários e o pessoal da escola, o supervisor de estágio também é surpreendido em suas contradições. 


\section{CONSIDERAÇões FINAIS}

Um aprendizado, que se destacou no curso das análises diz respeito à complexidade da relação de supervisão. Essa complexidade não está nos dizeres que não seguem uma sequência linear dos fatos, nem em ela abranger vários assuntos e situações, nem tampouco na diversidade de vivências experimentadas pelas estagiárias nas escolas. Ela está na trama das réplicas que constituem a relação de supervisão e na multiplicidade de vozes sociais nela implicadas.

"Cada réplica, por mais breve e fragmentária que seja, possui um acabamento específico e expressa a posição do locutor, sendo possível responder, sendo possível tomar, com relação a essa réplica, uma posição responsiva" (BAKHTIN, 2000, p. 294).

Da perspectiva das réplicas, a supervisão é uma relação na qual confluem muito mais do que as vivências do estágio, visto que os estagiários não abordam os acontecimentos vivenciados em si, mas o modo como cada um deles os significou nas condições específicas de produção do processo formativo, do estágio, das interações de que participaram nas escolas e da supervisão. O que os estagiários verbalizam, no conjunto das condições especificadas, é resposta a distintos enunciados (relativos às teorias e requisitos da formação acadêmica, a dizeres dos professores das escolas, a dizeres da própria supervisora, entre outros) que são dirigidas a distintos interlocutores (as demais estagiárias, a professora supervisora, os professores que os receberam na escola, os supradestinatários que configuram ideais de prática pedagógica, entre outros).

O teor e o estilo dessas réplicas dependem da situação concreta em que se produziram, do interlocutor a que se dirigiram, mas também, da história de cada estagiário, da sua experiência e de seus objetivos como estudantes, das exigências e requisitos do projeto de formação no qual estão inseridos, dos conhecimentos produzidos historicamente sobre a docência, a escola, a aprendizagem, o ensino aos quais têm acesso etc. A partir dessas contingências, cada estagiário apreende e elabora de uma maneira particular as situações produzidas no estágio e faz algumas opções em relação ao modo como as tematiza na supervisão.

Do mesmo modo que os estagiários, o professor supervisor também interpreta os acontecimentos relatados pelos estagiários, no contexto da supervisão, orientado por sua história, por sua experiência como supervisor e como professor, pelo projeto de formação em que está inserido, pelas exigências e requisitos desse projeto, pelas expectativas que tem em relação a seu papel dentro dele, pelas expectativas que reconhece em seus alunos (ou que atribui a eles), pelos conhecimentos produzidos historicamente sobre a docência, a escola, a aprendizagem, o ensino aos quais tem acesso etc. Ele também faz algumas escolhas em relação aos modos de se inserir na supervisão e de "responder" aos estagiários.

Na supervisão, indiciam-se, então, os encontros e confrontos entre os estagiários, os supervisores e demais interlocutores que trazem para essa relação, marcas da singularização dos sujeitos que dela participam e também as marcas dos embates que estagiários e supervisores vivem entre aquilo que são orientados a fazer, aquilo que intencionam (ou desejam) fazer e as condições concretas dos acontecimentos nos quais suas ações se inserem, bem como, suas escolhas em relação a como enunciar a passagem entre o pensado, intencionado, desejado e o realizado. 


\section{REFERÊNCIAS}

BAKHTIN, Mikhail. (VOLOCHINOV). Marxismo e Filosofia da Linguagem, 9. ed. São Paulo: Hucitec, 1999.

BAKHTIN, Mikhail. Estética da Criação Verbal, 3. ed. São Paulo: Martins Fontes, 2000.

CLOT, Yves. A função psicológica do trabalho, 2. ed. Petrópolis, Rio de Janeiro: Vozes, 2007.

FIORIN, José Luiz. Introdução ao pensamento de Bakhtin. São Paulo: Ática, 2006.

FONTANA, Roseli Aparecida Cação. O estágio curricular nos anos iniciais do ensino fundamental: apontamentos sobre o processo de inserção no campo de estágio. In: Olh@res, Guarulhos, v. 1, n. 1, p. 141-162, mai. 2013.

FONTANA, Roseli Aparecida Cação; PEREIRA, Valéria Lima. Do campo de estágio ao registro escrito: que percurso é esse? In: XIV Encontro Nacional de Didática e Prática de Ensino - ENDIPE. UNICAMP - Campinas, 2012.

FONTANA, Roseli Aparecida Cação. (s/d. [mimeo]). Contribuições da abordagem enunciativa de Bakhtin para a compreensão das elaborações dos sentidos da docência nos processos de formação inicial de professores. FE - UNICAMP.

FREIRE, Madalena. Refletindo, praticando, vivendo com as crianças da Vila Helena. In: Isto se Aprende com o Ciclo Básico, São Paulo, SE/CENP, 1986.

FREIRE, Paulo. Extensão ou Comunicação? Rio de Janeiro: Editora Paz e Terra, 1975.

ORLANDI, Eni Puccinelli. As formas do silêncio: no movimento dos sentidos. Campinas: UNICAMP, 1995.

SCHWARTZ, Yves. A comunidade científica ampliada e o regime de produção de saberes. In: Trabalho e Educação. Belo Horizonte, NETE, n. 7, jul./dez. 2000.

SCHWARTZ, Yves. Trabalho e Educação. In: Presença Pedagógica: Belo Horizonte, v. 7, n. 38, mar./abr. 2001.

SCHWARTZ, Yves. A experiência de conciliação de saberes produzidos em situação de trabalho com os saberes produzidos na academia. In: Trabalho e Educação. Belo Horizonte, NETE, v. 17, n. 2, mai./ago. 2008.

SCHWARTZ, Yves. Conceito, experiência, trabalho e linguagem. In: Trabalho e Educação. Belo Horizonte, NETE, v. 18, n. 3, set./dez. 2009. 
SMOLKA, Ana Luísa B. A criança na fase inicial da escrita: a alfabetização como processo discursivo. São Paulo: Cortez e Ed. da UNICAMP, 2001.

VIGOTSKI, Lev Semenovich. Manuscrito de 1929. In: Educação e Sociedade, Ano XXI, $n^{\circ} .71$, p. 21-44, 2000.

\section{DAdOS DA AUTORA:}

\section{Rita de Cassia Cristofoleti}

Doutora em Educação. Professora do Programa de Pós-Graduação em Ensino na Educação Básica do Centro Universitário Norte do Espírito Santo (UFES/CEUNES). São Mateus/ ES - Brasil. rita.cristofoleti@ufes.br

Submetido em: 9-6-2019

Aceito em: 8-1-2020 